\title{
風洞実験用空気静圧軸受型 4 分カロードセルの開発研究 4-components Wind Tunnel Load Cell with Aerostatic Bearing Methods
}

\author{
溝田武人*1 \\ 小栗弘規*2 \\ 鳴尾丈司*3 \\ 高塚達也 ${ }^{* 2}$ \\ 荒木友輔 ${ }^{* 2}$ \\ Taketo MIZOTA, \\ Hiroki OGURI, \\ Takeshi NARUO, \\ Tatsuya TAKATSUKA \\ Yuusuke ARAKI \\ 田北和幸 $* 2,4$ \\ 山元浩揮 ${ }^{* 2}$ \\ 長嶺 輝*2,4 \\ 田中克敏*5 \\ Kazuyuki TAKITA, \\ Koki YAMAMOTO, \\ Hikaru NAGAMINE, Katsutoshi TANAKA
}

\section{SUMMARY}

Aerostatic bearing load cell which is available to measure 3-components aerodynamic forces and torque is developed. Each table to detect the forces is floating by air pressure and balanced by a pair of coil springs. The model in the wind tunnel is connected with fine piano wires to a light frame on the unit. The wind loads acting on the model shift the each table within short distances. These shift magnitudes are measured with laser displacement devices. Aerodynamic torque is counted by spinning decay ratios of the model. As a result, this load cell has some specific characteristics to measure the forces, such as good linearity, high resolution, less interference and less temperature drift. The validity of this new apparatus is shown by the aerodynamic forces and torque measurements on highly spinning golf ball.

key words: wind tunnel, load cell, aerostatic bearing, less temperature drift, less interference

\section{1.まえがき}

風洞気流中で回転させた野球ボールやゴルフボールな どのスポーツボールに加わる定常空気力と回転軸まわり
の空力回転減衰トルクを精度よく測定できる 4 分力ロー ドセルを開発した。これは 3 方向に独立に微小変位する 移動部を空気静圧軸受とし，コイルばねでバランスさせ

\footnotetext{
* 1 福岡工業大学 名誉教授

Professor Emeritus of Fukuoka Institute of Technology

* 2 福岡工業大学工学部知能機械工学科

Department of Intelligent Mechanical Engineering, Fukuoka Institute of Technology

*3ミズノ株式会社

Mizuno Corporation

*4 福岡工業大学大学院知能機械工学専攻修士課程

Graduate Course of Fukuoka Institute of Technology

*5 東芝機械株式会社

Toshiba Machine Co., Ltd.

(原稿受理年月日：2015年7月 17 日，採用決定年月日：2015年12月 13 日）
} 
る基本構造になっている。風洞測定部中央にある供試模 型はピアノ線で吊られ，風洞外のフレームに繋がれてい る。フレームはロードセル上に乗っており, 模型に空気 力が作用すると 3 方向の移動部はわずかにその位置を独 立に変化させる。この変化量を各々測定すれば作用した 空力 3 分力を求めることができる。ボールの回転軸まわ りの空力回転減衰トルクを求めるには, 最初に与えた回 転速度が時々刻々減少するのでその変化を調べて, 求め ることができる。

このロードセルは出力直線性に優れ, 3 万向の荷重間の 相互干渉もなく, 荷重の分解能も小さく, 計測中の温度 ドリフトも少ない, などの優れた特性を有していること が分かったので報告する。

計測事例として，風洞気流中で高速回転するゴルフボ ールに作用する空気力およびボール回転に伴う空力回転 減衰トルクの測定結果を示した。

ゴルフボールの飛翔は与えられた初速 $U$ （最大值は 90 $\mathrm{m} / \mathrm{s}$ に達する), 回転速度 $N$ （最大值は $200 \mathrm{rps}$ に達する） に対して, 抗力 $D$ により速度が減速し, 揚力 $L$ で重力に 抗して上昇あるいは落下の程度を少なくする。横力 $S$ に よって左右に曲がる ${ }^{1)}$ 。回転速度 $N$ は空力回転減衰トル ク $M$ の作用で次第に減少する。

近年のゴルフは $300 \mathrm{~m}$ を超えるボール飛距離で競うの で 1\%(3 m)でも有利な飛距離のボールが選択される。そ のため抗力係数が低く揚抗比が高く, かつ空力係数がレ イノルズ数にあまり依存しないディンプル形状のボール の開発が常に望まれている。

一方，風洞気流中にある物体に加わる空気力を測定す る方法は古典的な天秤方式やゲージによるロードセル方 式など古くから開発されてきた。近年では磁力支持天科 装置 ${ }^{2,3)}$ も研究・開発されており, 実用レベルへの技術移 転が待望されている。

なお，スポーツボールの飛翔軌道を空気力から求める 場合, サッカーボールの弱回転魔球のように非定常空気

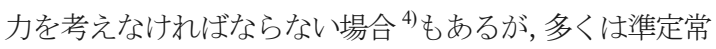
空気力で説明できる ${ }^{1)}$ 5)。この装置のように定常空気力 を精度良く測定できるロードセルは流体力学の多くの分 野において有効である。

\section{2. 使用した記号}

飛翔中のボールに加わる空気力 (抗力 $D$, 揚力 $L$, 横 力 $S)$ に対して, 空力 3 分力係数を $\left(C_{D}, C_{L}, C_{S}\right)=(D, L$, $S) /\left(0.5 \rho U^{2} A\right), \quad\left(C_{D}, C_{L}, C_{S}\right)=$ (抗力係数, 揚力係数, 横 力係数), と定義する。空力回転減衰卜ルクを $M$ とすれば,
$C_{M}=M /\left(0.5 \rho U^{2} A d\right), C_{M}$ : 空力回転減衰卜ルク係数である。 ここで, $\rho$ : 空気密度, $A$ : 直径断面積 $A=\pi d^{2} / 4, d$ : ボ 一ル直径である。空力 3 分力係数, 空力回転減衰卜ルク 係数はディンプル（形状，個数，配置）と流れに対する 回転軸の方向が定まれば, レイノルズ数 $R e=U d / v$ および スピンパラメータ $S p=\pi N d / U$ に依存して決まることが次 元解析から分かっている。ここで， $v$ : 空気の動粘性係 数, $N$ :ボールの回転速度, $S p=$ (回転によるボール表面接 線速度）/(ボールに対する空気の相刘速度)である。

\section{3．風洞測定部とロードセルおよび供試模型}

\section{1 風洞測定部とゴルフボールの安定回転機構}

風洞測定部(流路断面 $\times$ 長さ $=400 \times 400 \times 600 \mathrm{~mm}$ )の中 央にゴルフボールをピアノ線で釣り, 軽量のアルミ製フ

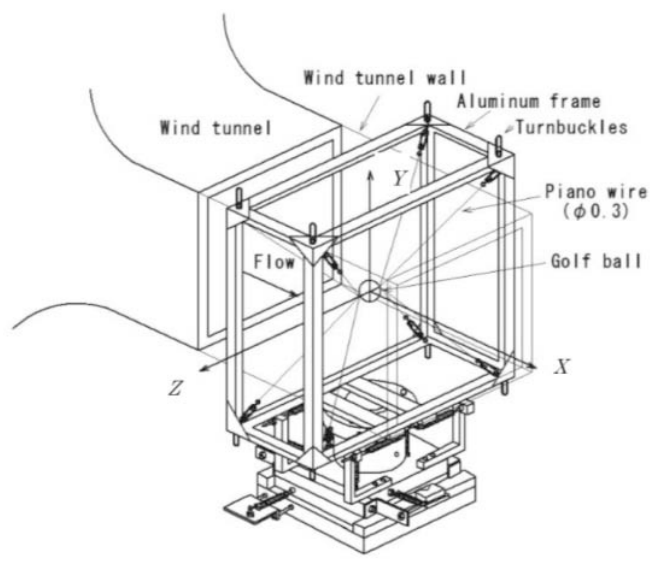

図 1 風洞測定部とゴルフボールのセット

Fig. 1 Set-up of golf ball in wind tunnel

レーム(高さ $\times$ 幅 $\times$ 流れ方向長さ $=700 \times 520 \times 300 \mathrm{~mm}$, 質 量 $1.2 \mathrm{~kg}$ )に接続した様子を Fig. 1 に示寸。フレームは口 ードセル上に載っている。ゴルフボールに加わった空気

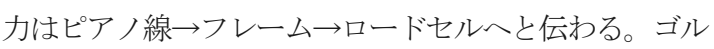
フボールは直径 $0.3 \mathrm{~mm}$ のピアノ線で吊られている。ピア ノ線は風洞壁に開けた直径 $10 \mathrm{~mm}$ の穴を非接触で貫通し, フレームに $100 \mathrm{~N}$ 程度の張力で接続されている。

Fig.2 にはゴルフボールを安定に自由回転させるための 機構を示す。静バランスを取るために, ボールの赤道上 に $120^{\circ}$ 毎に開けた 3 力所の小穴にセットボルト(M4 程 度) を入れ, その半径方向の位置を微調整する。調整後, ボール表面の 3 カ所の小穴はセロテープなどでふさいで おく。その結果, ゴルフボールは与えた初期回転速度 (200rps) から次第に低下寸る過程(後述の Fig.10(a)参照) で, 静止空気中でも風洞気流中でも安定に回転した ${ }^{6)}$ 。 


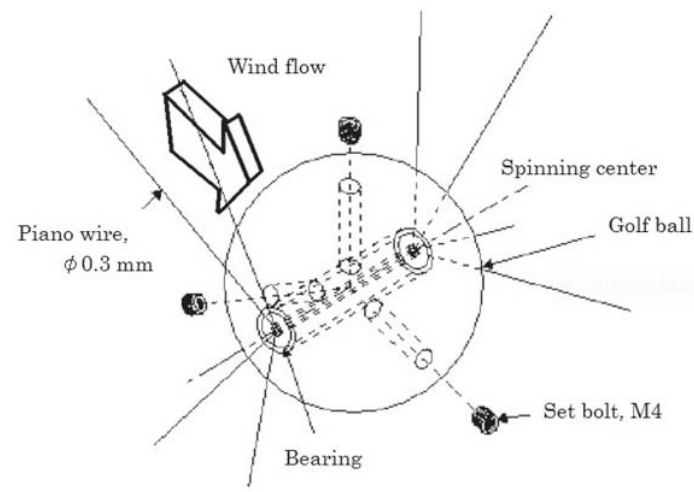

図 2 ゴルフボールの安定回転とバランス機構

Fig.2 Stable spinning golf ball consists of a shaft ( $\phi 10 \mathrm{~mm})$

with a pair of bearings, 4-piano wires ( $\phi 0.3 \mathrm{~mm})$ and

3 -setscrews on the equator of the ball.

ボールに回転を与える様子を Fig.3 に示す。実験では, 風洞気流が所定の流速に達した後に，ノズル気流をボー ル赤道面の接線方向に吹き付ける。例えば $U=40 \mathrm{~m} / \mathrm{s}$ の風 洞気流中でも 10 秒間程度の吹き付け時間で容易に $N=200$ $\operatorname{rps}$ の回転速度に達した。所定の回転速度に達したらノズ ル部分は速やかに風洞外に出して計測を開始するので, ノズルやそこから出る気流の影響は実験中には生じない。

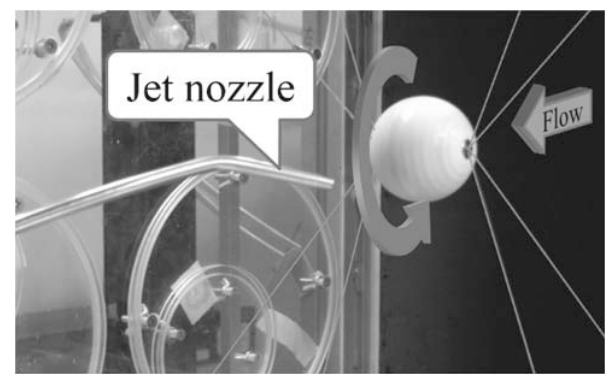

図 3 ノズル噴射気流によるゴルフボール回転

Fig.3 Golf ball spin by jet nozzle flow. After the objective spinning speed, the nozzle is quickly removed outside the test section. Golf ball is now backward spinning.

\section{2 荷重のキャリブレーション方法}

荷重のキャリブレーションのための治具を Fig.4(a)に示 す。キャリブレーションを行っている様子が Fig.4(b),(c) であるが，キャリブレーション荷重がプーリを経由して ボールに作用する方向を知印で示している。(b)は $+X$ 方 向（主流方向）へのキャリブレーションである。(c)は鉛 直 $+Y$ 方向へのキャリブレーションを行っている様子で ある。この場合, 治具を風洞測定部中心より上方に設置
して，回転摩擦の少ない 2 個のプーリを紐掛けして錘を 付加している。-Y方向はボールに紐掛けした錘による行う。

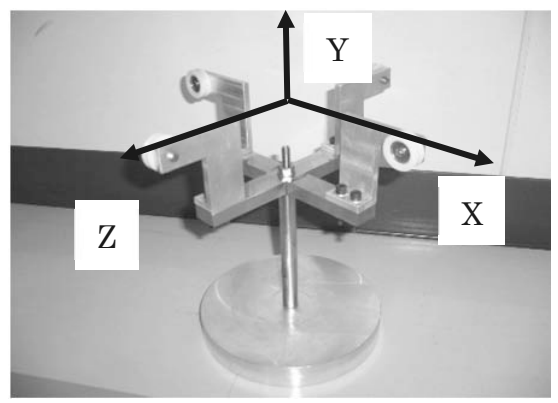

図 4(a)荷重のキャリブレーションのための治具

Fig.4 (a) Calibration device of load test.

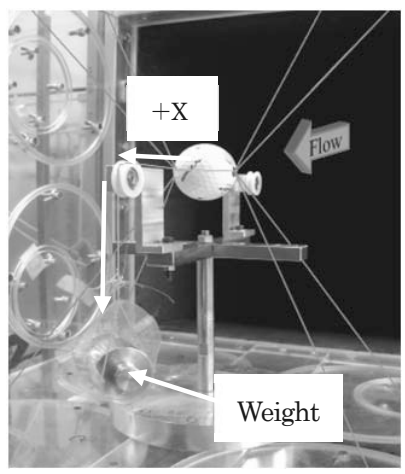

図 4 (b) $+X$ 抗力方向へのキャリブレーション

Fig.4 (b) Calibration of $+X$ drag direction.

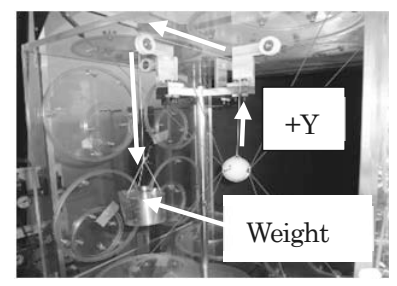

図 4 (c) $+Y$ 揚力方向へのキャリブレーション

Fig.4 (c) Calibration of $+Y$ lift direction.

図 4(a), (b), (c) キャリブレーション治具と抗力および揚 力方向試験

Fig.4 (a), (b), (c) Calibration device and method. Fig.4 (b) and (c) show the calibration toward $+X$ drag and $+Y$ lift direction.

この治具を使うことにより, 後述(5.1 出力直線性と干渉 の程度)のような正確なキャリブレーションが実現した。

3. 3 風洞測定部へのロードセルの設定

Fig.5 に風洞測定部とロードセルを配置した写真を示す。 
Fig.5(a)は測定部全体を示し，Fig.5(b)は風洞流路の下側に 置いたロードセルなどを示す。

Fig.5(a)の(1)は透明な風洞測定部壁面，(2)はゴルフボー ルであり, (3)の光反射式回転計により, 風洞外部からボ ールの回転速度を調べる。そのためボールの回転軸近く で比較的流れに影響を与えない表面にガラスビーズの反 射シールが貼ってある。(4)がアルミ製フレームである。 (5)はロードセル (Fig.5(b)の9参照) であり，その上にフ レームは乗っている。(6) 4.2 外乱補正の方法, の所で述 べるが Dummy の揚力検出器である。揚力方向には構造 上大気圧変動などの外乱が現れるのでそれをキャンセル するために設けている。(7)は 3 分力方向への検出器に圧 縮空気を安定化して送る調整バルブやレギュレータを配 置したユニットである。

Fig.5(b)の8)（Fig.5(a)の(4)に同じ）はフレームで99のロ ードセルの揚力検出部分の上に乗っている。この上下 Y 方向移動量は(10のセンサにより検出する。揚力検出部(9) は111の X方向移動台に乗っていて, その移動量 Xは120 センサにより検出する。X 方向移動台(11)は(13)の Z 方向移 動台に乗っており，その移動量 Z は(144のセンサで検出寸 る。

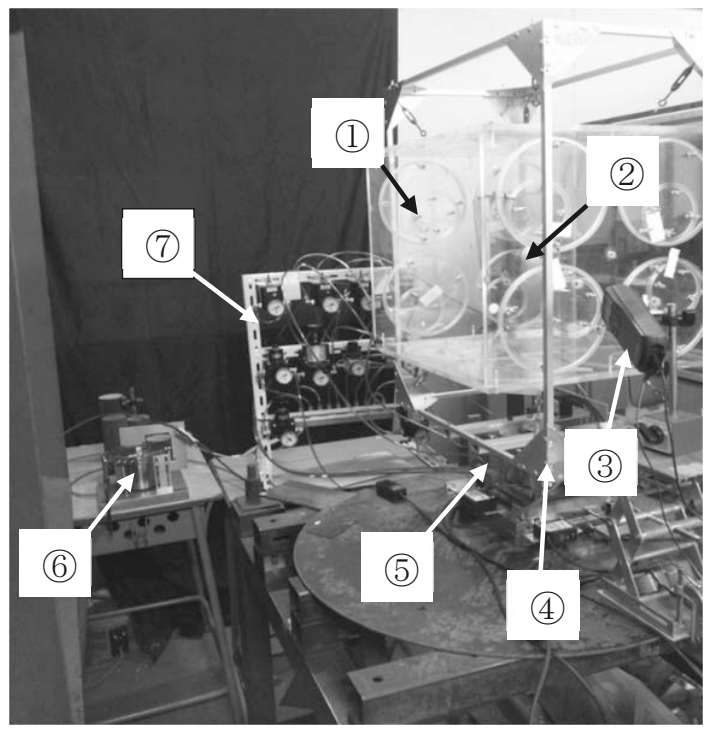

図 5(a) (1) : 風洞測定部壁面, (2) : ゴルフボール, (3) : 回 転速度の測定器, (4) : フレーム, (5) : ロードセル, (6) : ダミ 一のロードセル (揚力検出部のみ) (7) : 空気圧調整ユニット Fig.5 (a) (1): Wind tunnel wall, (2): Golf ball, (3): Tachometer for golf ball spinning speed, (4): Aluminum frame, (5): Active load cell part (same as Fig.5(b) (9), (6) : Dummy part of lift actuator, (7) : Air pressure regulator of each direction.

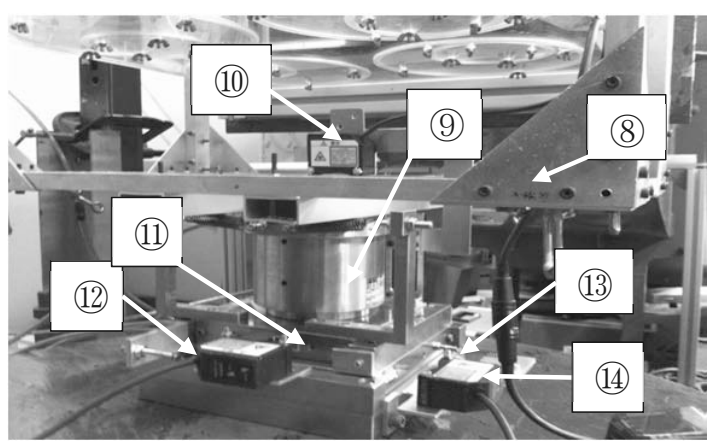

図 5(b) 3 分力ロードセルの部分

(8) : フレーム部で Fig.5(a)の(4)に同じ。(9)と(10) : $Y$ (揚力) 方向移動部と変位検出センサ, (11) と(12) : $X$ (抗力) 方向移

動部と変位検出センサ, (13)と(14)：Z(横力)方向移動 部と変位検出センサ, (9), (11), (12), (13)はFig.6 も参照。

Fig.5 (b) Main part of the 3-components load cell, on which 1.2 $\mathrm{kg}$ aluminum frame is mounted, and 3 sensors position. (8) : Frame part same as shown in Fig.5(a) (4). (9) and (10): $Y$ (Lift) direction and sensor for small deflection of Y-direction, (11) and (12) : $X$ (Drag) direction and sensor for $X$-direction, (13) and (14):

$Z$ (Side force) direction and sensor for $Z$-direction.

図 5(a),(b) 風洞測定部のセットアップ

Fig.5 (a), (b) Set-up of wind tunnel test section

風洞測定部の 4 壁面は 4 個の回転可能な円盤 $(\phi 80 \mathrm{~mm})$ で構成されており, 各円盤には回転可能な円盤 $(\phi 40 \mathrm{~mm})$ が 1 個組み込まれている。小さい円盤の外周近くにはピ アノ線が非接触で貫通できる小穴が開けてある。 $\phi 40$ $\mathrm{mm}$ 円盤と $\phi 80 \mathrm{~mm}$ 円盤を回してピアノ線の貫通位置を 各壁面内の $\phi 80 \mathrm{~mm}$ 円盤内で自由に決めることができる。

\section{4. 空気静圧軸受型 4 分力ロードセルの作動原理と 外乱補正}

\section{1 空気静圧軸受を用いた 3 方向浮上機構と 変位量測定}

Fig.5(a),(b)の写真でも示したが, 空気静圧軸受型の 3 分 カロードセルの基盤部分を Fig.6 に立体図で示す。図中の 番号はFig.5(b)の番号と同じ部分を示す。座標系を左上方 に示している。上から, 揚力, 抗力, 横力の移動部を重 ねて設置している様子や微小変位を検出するレーザ変位 計などが見える。抗力と横力は図中 $(D, S)$ と記入した 方向に作用寸る。

移動部は空気静圧軸受で構成されている。直線運動す る各移動部 $D, S$ には $0.4 \mathrm{MPa}$ の圧縮空気が供給され, 30 $\mu \mathrm{m}$ 程度の軸受すき間で浮上している。各々 $\Leftrightarrow$ 印で示す 
水平方向に自由に移動させることができ, コイルばねで 平衡位置を保っている。

Fig.6 に $L$ と記入された $Y$ 万向の移動部は中心の Base 部とそれを囲む円筒状の Slide 部で構成されている。半径 方向および上下方向ともに円筒状の空気静圧軸受で支持 されている。軸受寸き間は $30 \mu \mathrm{m}$ であり, 上下方向, 回 転方向へ動く自由度がある。Slide 部と Base 部(軸)の中間 位置に直径差がある。この直径差の部分に作用する空気 静圧が Slide 部に上向きの力を発生する。Slide 部の 3 本の コイルばねで下方に引っ張り，平衡位置を保っている。

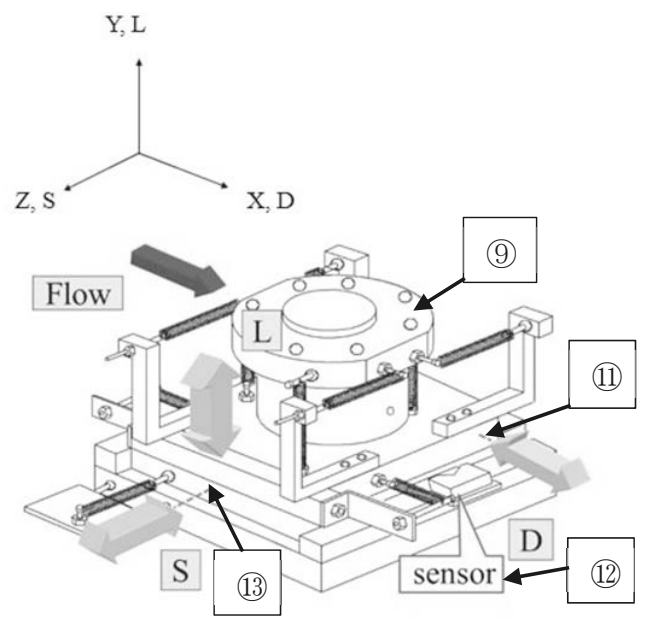

図 6 空気静圧軸受型 3 分力ロードセル (図中の番号は図 5(b)に同じ部分を示す)

Fig.63-components load cell by aerostatic bearing method (Number are same as Fig.5 (b).)

この平衡状態で風洞内の供試模型に抗力, 揚力, 横力 などの空気力が作用すると, それぞれの移動部がわずか に移動する。この移動量を計測すると空気力が分かる。

供試模型に加わった空気力によって, おのおのの移動 部は最大 $1.5 \mathrm{~mm}$ 程度シフトする。コイルバネの剛性はそ のように選んでいるが，計測荷重に応じてコイルばねの 剛性は自由に選択できる。

$(X, Y, Z)$ 方向へのフレームのシフト量は Fig.5(b)や Fig.6 で示したレーザ変位計で測定する。レーザ変位計の距離 測定は $30 \mathrm{~mm} \pm 2 \mathrm{~mm}$ の範囲で有効である。変位計のレー ザビームの中心(直径 $75 \mu \mathrm{m}$ )がその範囲に入るように 10 $\times 20 \mathrm{~mm}$ の表面寸法の反射鏡面を移動部に接着している。 レーザ変位計の分解能は $0.25 \mu \mathrm{m}$ であるので, フレーム の許容最大移動量を $2 \mathrm{~mm}$ に制限すると $0.0125 \%$ の変位分 解能を有することになる。

\section{2 外乱を補正する方法}

実験中,供給圧が作動適正範囲内で变化しても,また大 気圧や実験室の室内圧が変化しても $X, Z$ 方向の水平方向 への移動部は, 受圧面の構造上, その影響を受けない。 一方, $Y$ 方向の揚力は供給圧, 大気圧, 室内圧が変化す るとその影響が直接現れる。そこで，これらの外乱が作 用した際には, キャンセルさせる必要がある。そのため に, フレームを載せる Active 装置と同じ構造の Dummy 装置をFig.5(a)の(6)に示したように別に設けた。

Fig.7 は Active 装置, 揚力の Dummy 装置からの信号の 流れを示すブロック図である。揚力の Active 装置からの 信号は $Y=$ 揚力十供給圧変動十大気圧変動十室内圧変動か らなり, Dummy 装置からの信号は $Y$ 供給圧変動十大気 圧変動十室内圧変動からなる。 $Y-Y=L$ が揚力を表寸信号 となる。各アナログ信号は $0.3 \mathrm{~Hz}$ のローパスフィルタを 介した後にコンピュータで処理している。

ちなみに大気压変動は気象条件によって大きく異な るが, 前線が通過する場合には 10 分間で $0.05 \sim 0.6 \mathrm{hPa}$ 程 度は変化する事例が報告されている7。この変化はゴルフ ボール重量の 0.33〜3.3\%に相当するノイズとなるので 好ましくない。そこでこのノイズはキャンセルされる構 造にしている。キャンセリングの結果は, 5.2 揚力方向の 外乱出力のキャンセリング結果, に示す。

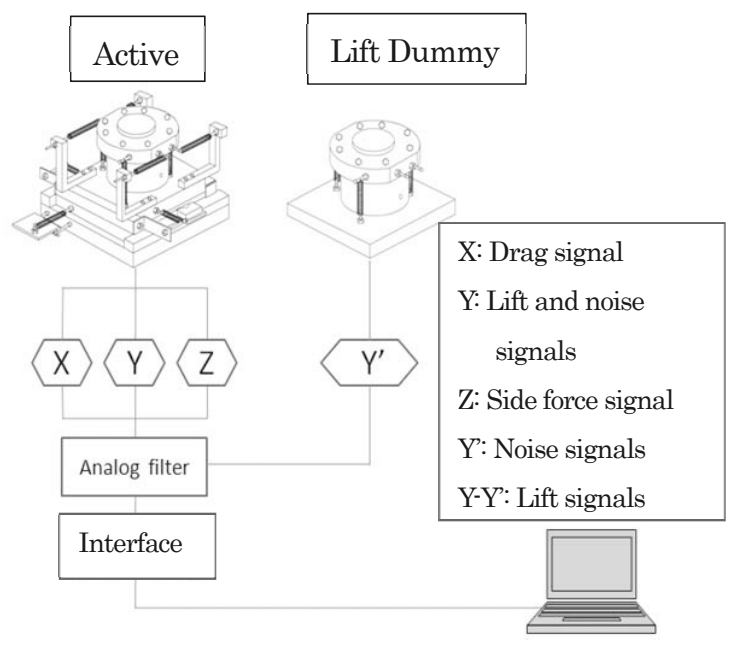

図 73 分力の信号検出ブロック図, $(X, Y, Z)$ 方向の信号 と $Y^{\prime}$ は揚力のダミ一装置からの信号。各信号には $0.3 \mathrm{~Hz}$ のローパスフィルタを介している。

Fig.7 Block diagram of 3-components signal detection system.

$(X, Y, Z)$ signals are active ones, and $Y^{\prime}$ is for noise of lift detection. $Y-Y$ ' signal is available as the pure lift signal. Each signal is processed after $0.3 \mathrm{~Hz}$ low pass filter. 


\section{5.ロードセルの各種特性に関する検討}

5. 1 出力直線性と他の 2 方向への干渉の程度

このロードセルの 3 分力 $(X, Y, Z)$ 方向へのキャリブレ ーションテストによる出力直線性と他の軸への干渉程度 を調べた結果を Fig.8(a), (b), (c), (d)に示す。荷重を-2.0 + $2.0 \mathrm{~N}$ の範囲で 3 方向に加えた場合の出力電圧の直線性を 示している。図中 $R^{2}$ の值は決定係数である。なお，抗力 と横力の同時キャリブレーションテストも別に行ってい る。

これらに加えて揚力方向については $0.01 \mathrm{~N}$ きざみでキ ヤリブレーションテストを行った。Fig.8(c)は揚力(-Y)方 向に-0.4 N の荷重を加えた状態でさらに-0.01 N 刻みで荷 重を増した場合の出力直線性を調べた結果である。これ は，ゴルフボールのディンプル形状を変化させた場合の 揚力のわずかな出力変化を調べることを想定している。

これらの試験結果から，以下のことが分かった。

(1) いずれの方向の出力直線性も良好で, 他分力への干渉 程度も極めて少ない。

(2) 荷重分解能は $0.01 \mathrm{~N}$ 程度であった。

(3) 実験中の温度ドリフトもほとんど発生しなかった。

5. 2 揚力方向の外乱出力のキャンセリング結果

Active 装置の出力信号 $Y$ から Dummy 装置からの信号 $Y^{\prime}$ を差し引く方法により，揚力方向の外乱を演算回路でキ ヤンセリングさせた結果を以下に示す。

Fig. 9(a) の図中の各番号の時間帯で,

1 : 荷重 $0.2 \mathrm{~N}$ を Active 装置にの夕負荷・除荷して, Output 信号はそれに追従(Active 装置と Output 信号が重なっ ている)している,

2 : Dummy 装置に負荷・除荷して Output 信号はマイナ ス信号となって追従している，

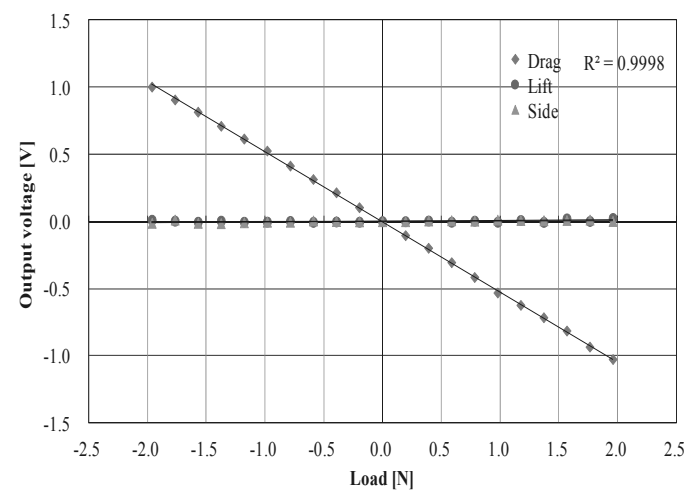

図 8(a) $X$ (抗力)方向の出力直線性と $Y, Z$ 方向への干涉

Fig.8 (a) Output linearity of $F_{D}=-2.0 \sim+2.0 \mathrm{~N}$ by $X$ (drag) direction load. Less interference output toward $\mathrm{Y}$ (lift) and $\mathrm{Z}$ (side force) directions by $F_{D} \cdot R^{2}$ means coefficient of determination.

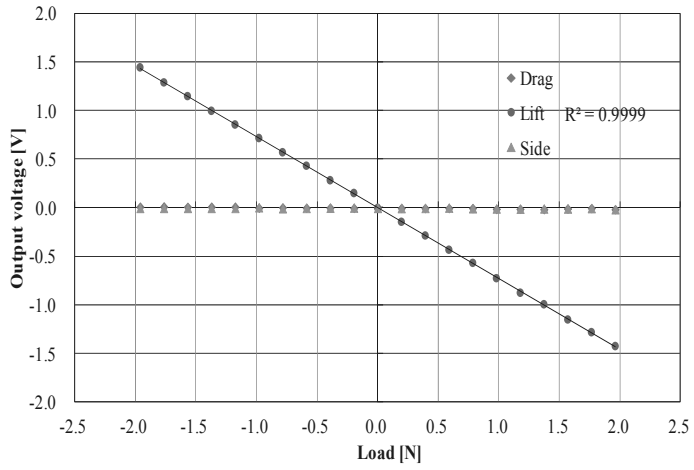

図 8(b) $Y$ (揚力) 方向への出力直線性と $X, Z$ 方向への干涉

Fig.8 (b) Output linearity $F_{L}=-2.0 \sim+2.0 N$ by $Y$ (lift) direction load. Less interference output of $X$ (drag) and $Z$ (side force) directions by the load $F_{L}$

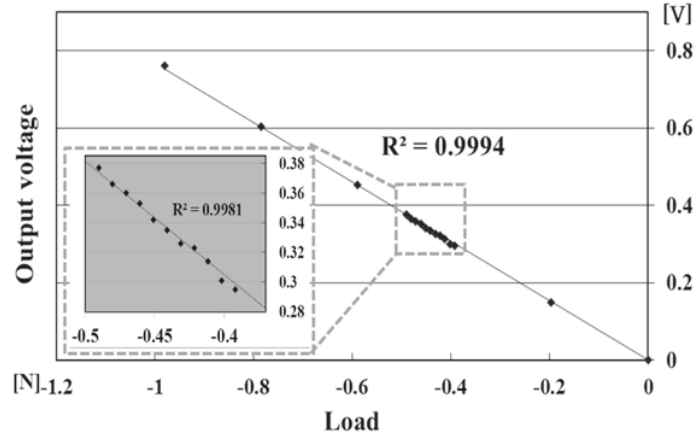

図 8(c) $-Y$ (-揚力) 方向へのキャリブレーションと $0.01 \mathrm{~N}$ ステップのキャリブレーションの直線性

Fig.8 (c) Output linearity by small step loads by $Y$ (lift) direction load $\mathrm{F}_{\mathrm{L}}=0 \sim-1.0 \mathrm{~N}$, including $F_{L}=0.01 \mathrm{~N}$ steps between $-0.4 \sim$ $-0.5 \mathrm{~N}$.

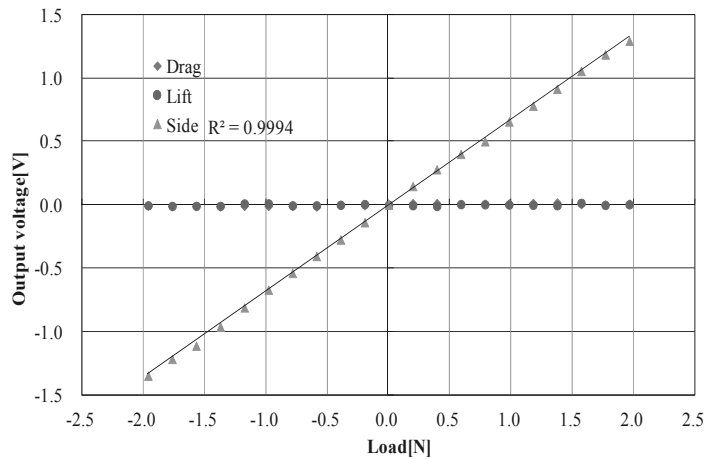

図 8(d) Z(横力)方向の出力直線性と $\mathrm{X}, \mathrm{Y}$ 方向への干渉 Fig.8 (d) Output linearity of $Z$ direction load $F_{Z}=-2.0 \sim+2.0 \mathrm{~N}$. Less interference output toward $X$ (drag) and $Y$ (lift) directions.

図 8(a),(b),(c),(d) 3 分力の出力直線性と他の方向への干 渉の程度

Fig.8(a),(b),(c),(d) Output linearity of each direction and interference output toward other directions. 
3 : 両者(重なっている)に負荷・除荷して, Output信号は キャンセルされてゼロになっている， という状況であった。

Fig. 9(b) は荷重を $1 / 10$ に軽くして $0.02 \mathrm{~N}$ 載せた場合の 実験結果である。Gain を 10 倍に上げて出力しているので 信号には $0.002 \mathrm{~N}$ レベルのノイズが現れているが, 両装置 に負荷・除荷した 1 2 3 の過程で演算回路が示寸信号が 現れている。

両装置に荷重を乗せた状態で, 供給する空気静圧を意 図的に変化させた場合の実験結果を Fig. 9(c)に示寸。

この結果は以下のようにまとめられる。

1 : Active 装置に-0.2N 負荷すると, Output信号は Active 信号と重なって現れている。

2 : Dummy 装置に- $0.2 \mathrm{~N}$ を負荷すると, Output 信号は反 転されてプラス側に現れる。

3 : 両者に- $0.2 \mathrm{~N}$ 負荷したままで, 供給空気圧をわずかに 変化させると, それぞれの装置からの出力は大きく 変化しているが，それらをキャンセルした Output 信 号はほぼ正しく現れている。

以上のようにキャリブレーションの結果を示寸 Fig8(c)や ノイズレベルのテストを示寸 Fig.9(b)を総合して，このロ ードセルの最小荷重分解能は $0.01 \mathrm{~N}$ 程度と考えられる。

6. 空力回転減衰トルクの計測方法とその結果

ゴルフボールのように高速で回転して $300 \mathrm{~m}$ も飛翔す る 5 6 秒間の過程ではボールの回転速度が空力回転減衰 トルクにより低下寸る。飛翔軌道は, 時刻 $t$ のボール位置, 速度, 回転速度から $\Delta t$ 後 (実際の計算では $\Delta \mathrm{t}=0.005$ 秒程 度)後の回転速度と速度および位置をニュートン法から 求める ${ }^{1)} 。 \Delta t$ の間は空力回転減衰トルク(Fig. 10(b))およ び空力係数(Fig.12)の值が一定值(ボール移動距離では最 大で $45 \mathrm{~cm}$ 程度)としている。

風洞実験により空力回転減衰卜ルクを求めるには以下 の 2 つ方法が考えられる。

(1) ボールの自由回転速度の減衰割合から角加速度を求 める。

（2）ボール中心に一本のピアノ線を貫通させてそれを介 して風洞外部の片側からモータでボールを気流中で 回転させ，その時のピアノ線の㨭れ角度からトルク を測定する。

(2)の方法は文献 1)にすでに記述しており, 飛距離の計算 と実測によって自由回転減衰係数 $C_{M}$ の測定結果の正し さも実証済みである。ここでは(1)の方法により空力回転 減衰トルクを測定した。そこで前述の Fig. 2 に示したよ

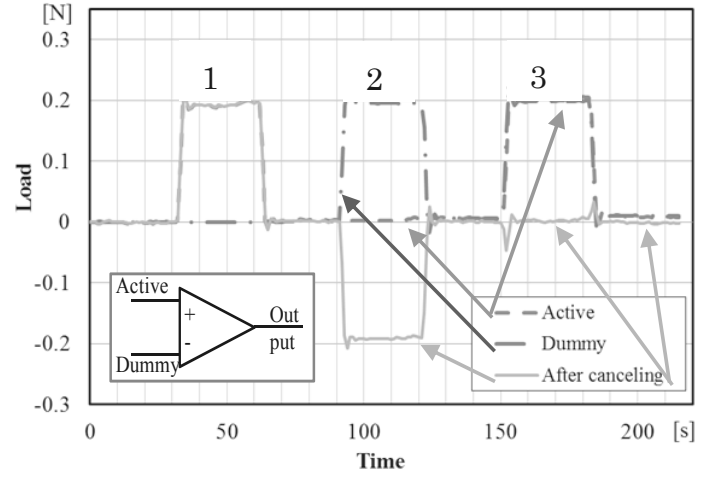

図 9(a) キャンセル信号（Active 装置および Dummy 装 置に順次 $0.2 \mathrm{~N}$ を負荷した場合）

Fig.9 (a) Output signals under $0.2 \mathrm{~N}$ load test. Nil resultant signals in the same load or unload time.

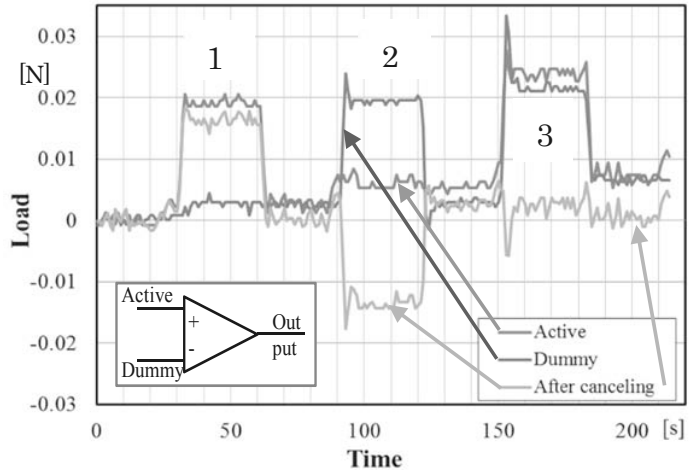

図 9(b) キャンセル信号 (Active 装置および Dummy 装置 に $0.02 \mathrm{~N}$ を順次負荷した場合）

Fig.9 (b) Output signals under $0.02 \mathrm{~N}$ load. Nil resultant signals in both same load or unload time.

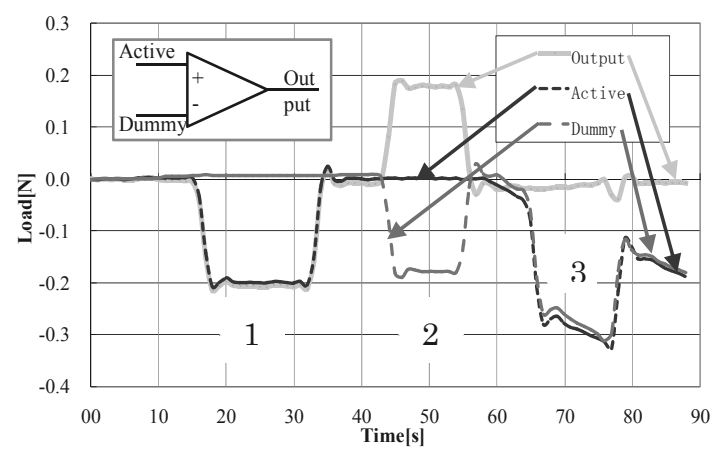

図 9(c) 供給圧を変化させた場合のキャンセリング

Fig.9 (c) Cancelled signals under changing supplied air pressure

図 9(a),(b),(c) 揚力方向の出力安定性試験

Fig.9(a),(b),(c) Cancelled output signals of $Y$ (lift) direction under (a), (b) same weight and (c) changing supplied air pressure on active and dummy units. 
うに，ボール内部にミニチャベアリングを挿入して，自 由回転減衰させる機構を製作した。これを使って静止空 気中や色々な流速中で回転速度が減少する時間履歴を調 べた結果を Fig. 10(a)に示す。

静止空気中では主にベアリングの機械的な回転摩擦抵 抗と静止空気の中で回転する際の空気摩擦抵抗の両者が 作用する。このシステムでは $200 \mathrm{rps}$ から $20 \mathrm{rps}$ まで 180 秒程度でゆっくりと回転速度は減少した。風洞気流中で は空力摩擦トルクによりこの時間は 60 秒程度に減少した。 これらの違いから空力回転減衰卜ルク係数を求めた結果 を Fig. 10(b) に示す。ただしこの結果は, 機械的な摩擦卜 ルクだけでなく, 静止空気中の空力摩擦トルクの両方が 取り除かれている。

図中印は実際に飛翔しているボールの回転速度をレ ーダで計測して空力回転減衰トルクを求めた結果である 8)。印は前述の(2)の方法によりピアノ線の㧖れ角度から 求めた結果であり ${ }^{9)}$, その近似曲線を実線で記入している。 この結果と歪ゲージ式のロードセルで測定した空力 3 分 力係数を使って行った飛翔軌道計算は実験で正しさが確 認されている ${ }^{1)}$ 。今回の実験によって自由回転減衰法によ っても空力回転減衰トルクを求めることができた。

実際に飛翔中のボールで計測した結果 ${ }^{8)}$ とも比較した が，ゴルフボールがそれぞれ異なるためか，スピンパラ メータ $\mathrm{Sp}$ の変化にともなう空力回転減衰卜ルク係数 $\mathrm{C}_{\mathrm{M}}$ の特性にはこの程度の違いがある。 $\mathrm{C}_{\mathrm{M}}$ の違いは飛距離の 特性に現れるので空力回転減衰トルクの計測結果の妥当 性については, 飛翔軌道の計測実験などによって今後確 認したい。

\section{7. その他の検討事項}

7. $1 X$ および $Z$ 方向の Slide 部の上下方向の安定化 圧縮空気の供給能力から，このロードセル全体に供給 される流量 $Q$ は $Q=610 \mathrm{~L} / \mathrm{min}$ であり, 供給圧力は $P_{S}=0$. $75 \mathrm{MPa}$ であった。 $X$ 方向, $Z$ 方向に移動するテーブル (Fig.4 の $X, Z$ 方向)は空気静圧軸受けで支持されており, 各供給箇所に高性能レギュレータを介して $0.4 \mathrm{MPa}$ の圧 力変動の少ない圧縮空気を供給し, 軸受け寸き間の安定 化を図っている。各テーブルは装置の小型化と構造の簡 素化を目的に真空圧と静圧をバランスさせる静圧軸受方 式を採用し，上下方向の位置(軸間すき間)を保持している。 これらの移動部の軸受寸き間は $30 \mu \mathrm{m}$ であるが, 荷重 の条件などによって，ニューマチックハンマ (pneumatic hammer instability) と呼ぶ不安定現象が発生することがあ る。供給する空気流量や空気圧から， Slide 面にかかる荷

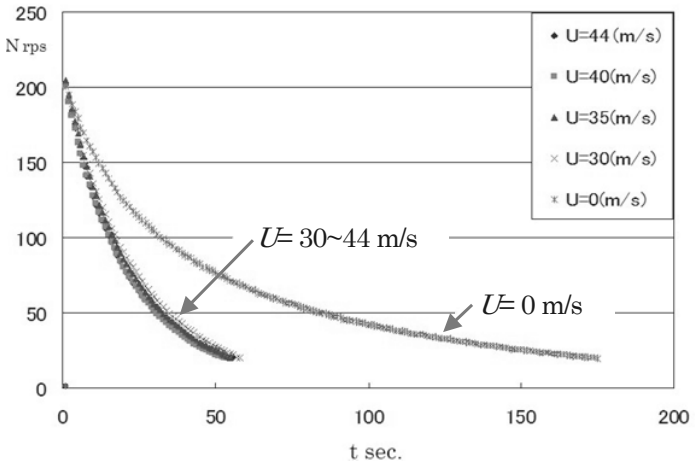

図 10(a) 静止空気中と一様流中（ $U=30 \sim 44 \mathrm{~m} / \mathrm{s} ）$ における ゴルフボールの回転速度の変化

Fig.10 (a) Time-decay of spinning speed of golf ball in still air and wind tunnel flow $(U=30 \sim 44 \mathrm{~m} / \mathrm{s})$.

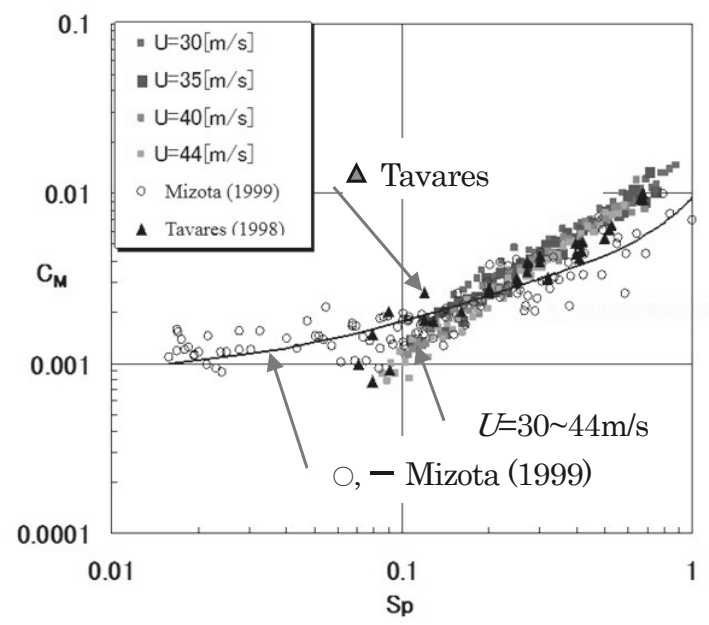

図 10(b) 空力回転減衰卜ルク係数の測定別比較

Fig.10(b) Comparison of aerodynamic torque coefficient $C_{M}$ with measured by the rader ${ }^{8)}(\mathbf{\Lambda})$, twist angle of piano wire ${ }^{9)}$ ( $\bigcirc$ and its approx. line) and present results.

図10(a),(b) 空力回転減衰トルクによるゴルフボールの(a) 回転速度の減少と(b)空力回転減衰トルク係数の測定

Fig.10(a), (b) Spinning speed and aerodymanic torque coefficients of golf ball.

重の最適条件を調べておく必要がある。

7. 2 揚力方向の安定位置とフレーム重量

揚力を測定するための円筒状部分は中央の Base 部を固 定し，その周囲を Slide 部が $0 \sim 10 \mathrm{~mm}$ の範囲で上方に動 く構造になっている。Slide 部と下面の Base 部の隙間は狭 い方が安定であったので, $2 \mathrm{~mm}$ 程度の隙間で作動させる ように 3 本のコイルバネのバネ定数を選定した。 
フレームは揚力を測定する部分の上に載る。その質量 の違いによる出力のノイズを調べた。その結果 $3.0 \mathrm{~kg}$ の 場合に比べ $1.0 \mathrm{~kg}$ の場合の出力ノイズが $1 / 3.7$ まで低下し た。そこで $1.2 \mathrm{~kg}$ の質量のフレームを製作した。Fig.11 にはフレーム質量の違いによるノイズの変化を示寸。 1.2 $\mathrm{kg}$ と $3.0 \mathrm{~kg}$ のフレームに $0.02 \mathrm{~N}$ の荷重を, 負荷・徐荷した

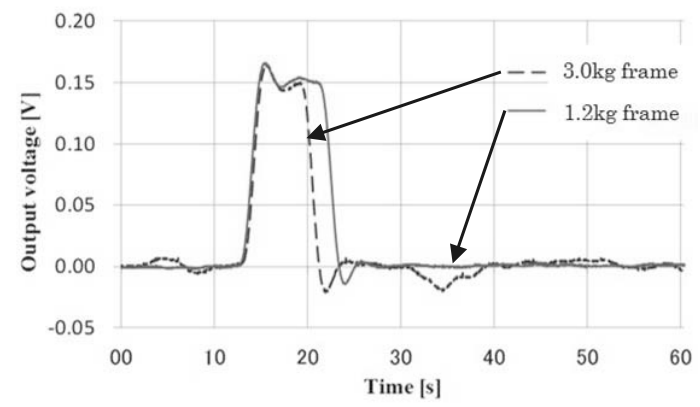

図 11 フレーム質量の違いによる負荷時の出力安定性 $(1.2 \mathrm{~kg}$ および $3.0 \mathrm{~kg}$ のフレームに $0.02 \mathrm{~N}$ の荷重を揚方 向に負荷・除荷した場合の出力安定性を示す)

Fig.11 Fluctuation noise with $3.0 \mathrm{~kg}$ and $1.2 \mathrm{~kg}$ frame mass load : Output voltages of 0.15 Volts equivalent to $0.02 \mathrm{~N}$ load.

場合の出力の安定性を示している。したがって,このロー ドセルとコイルバネの組み合わせでは, 荷重分解能 0.01 $\mathrm{N}$ に対するフレーム重量 $11.8 \mathrm{~N}$ の比率(ペイロード比)は $8.47 \times 10^{-4}$ 程度となる。

\section{3 レーザ光の反射鏡}

各方向の変位測定にはレーザ光反射型の变位計を用い ている。 $X, Z$ 方向のテーブルや $Y, Y$ '方向の円筒部に付け た鏡面でレーザ光を反射させる方式である。ガラスビー ズ型の反射鏡ではビーズの凹凸を感知して変位量に不都 合が生じた。これを良質の反射鏡面に変更することで解 決した。

\section{8. 高速回転するゴルフボールの空気力の測定事例}

このように種々の検討を加えて開発した空気静圧軸受 型ロードセルにより，風洞気流中で高速回転するゴルフ ボールに加わる空気力の抗力係数 $C_{D}$ および揚力係数 $C_{L}$ を測定した結果を Fig.12 に示寸。比較的ばらつきの少な い結果が得られている。

この実験の最大流速は $U=44 \mathrm{~m} / \mathrm{s}$ であるが, 別途行った 実験により $30 \mathrm{~m} / \mathrm{s}$ 以上では空力特性はほとんど変化しな いことを $U=90 \mathrm{~m} / \mathrm{s}$ までの流速で確かめている。

最近のボールでこのように広い $\mathrm{Sp}$ の範囲で空力係数 を調べた他の測定事例は見当たらない。文献 11)の結果の
$\mathrm{Sp}=0.02 \sim 0.3$ の計測範囲で比較すると，抗力係数はあまり 変化がないが, 最近のボールは揚力係数が大きな值を有 するように改善されており，揚抗比が大きくなっている。

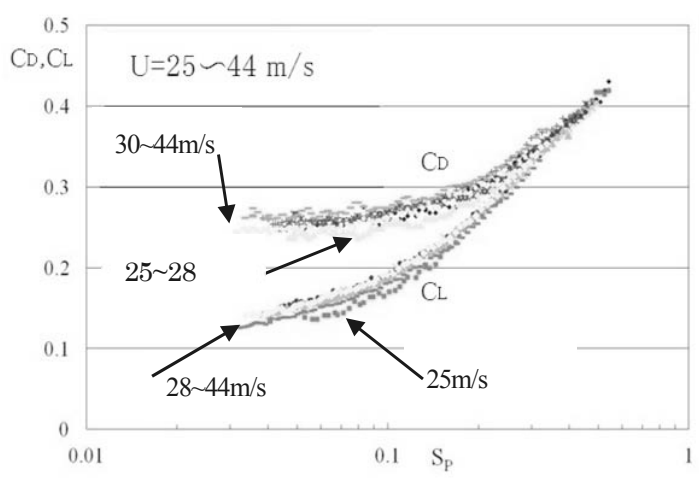

図 12 本装置で計測したゴルフボールの抗力係数と揚力 係数の一例

Fig.12 An example of aerodynamic characteristics on highly spinning golf ball measured by the air suspended load cell.

なおここれでの風洞実験では定格 $50 \mathrm{~N}$ の歪ゲージ式 のロードセルを利用して計測を行ってきた。風洞実験の 際には，温度ドリフトや荷重分解能などに細心の注意を 払うことによって，実用的にも信頼性の高い空力データ を得ている。すなわち得られた空力係数を基に飛翔距離 の計算を行い，その結果が飛翔実験結果と良く一致した ことを確認している1)。これらの結果, 最近では新しいコ ンセプトに基づくディンプルが加わったゴルフボールの 開発に成功している ${ }^{10)}$ 。

今後は今回開発した空気静圧受軸型ロードセルによっ て，さらに高い信頼性と高精度のデータを得ることが出 来ると考えている。

\section{9.この研究で得られた結論}

風洞気流中にある物体に加わる定常空気力の内の 3 分 力と空力回転減衰卜ルクを高精度で求めることが出来る 空気静圧軸受型のロードセルを開発した。このロードセ ルの出力直線性や他軸への出力の干涉，荷重分解能，温 度ドリフトを調べた。大気圧や供給空気圧の変動などの 外乱をキャンセリングする必要がある揚力の検出には Dummy の装置を設けて解決させた。実際に高速回転させ たゴルフボールに加わる空力 3 分力およびボール回転軸 まわりの空力回転減衰トルクを測定した。得られた結論 は以下の通りである。

(1) 本ロードセルは $X, Y, Z$ 方向の出力直線性は十分に良 
く，他の軸への干渉も極めて少ない。

(2) それぞれの方向の $0.01 \mathrm{~N}$ レベルの空気力を測定でき る分解能がある。

(3) 大気圧変動や供給圧の変動および温度ドリフトなど の外乱には Dummy 装置を設けて, 安定した出力特 性を得た。

(4) 空力回転減衰トルクを自由回転減衰法により求めた。

謝辞

この研究を行うにあたり福岡工業大学工学部知能機 械工学科加藤友規准教授及び工作センターの方々には 研究上のご教示と機器の貸与に関して種々の便宜をは かって頂いた。記して謝意を表する。この研究の一部は 2007 2008 年度文部科学省科学研究費, 基礎研究, 課題 番号 19500555 の資金で行われた。

\section{参考文献}

1）鳴尾 丈司, 溝田 武人，「ゴルフボールの空気力測定 と 3 次元飛翔軌道解析」, 日本流体力学会誌 “なが れ”, 第 23 巻, 第 6 号, pp. 203-211, (2004)

2）澤田 秀夫, 国益徹也，「低速風洞用 $60 \mathrm{~cm}$ 磁力支持 装置の開発」, 日本航空宇宙学会論文集, 第 50 巻, 第 580 号, pp. 188-195, (2002)

3) Kawamura, T. and Mizota, T., "Advanced Magnetic Suspension and Balanced System Having Characteristics of Light Weight", Electric Power Saving, and Fast Response, Transactions of the ASME, J. of Dynamic Systems, Measurement, and Control, Vol. 134, Number 4, pp. 044502-1 - 044502-7, (2012)

4) Mizota T., Kurogi K., Ohya Y., Okajima A., Naruo T. and Kawamura Y., "The Strange Flight Behavior of Slowly
Spinning Soccer Balls", www.nature.com/srep, nature, SCINTIFIC REPORTS, |3:1871| DOI: 10.1038/ srep 01871, pp. 1-7, (2013)

5）溝田 武人, 久羽 浩幸, 岡島 厚,「ナックルボールの 不思議? (第 1 報 準定常理論による飛翔解析とフ ラッタ実験) 」, 日本風工学会誌, No. 62, pp. 3-13, (1995)

6）鳴尾 丈司, 溝田 武人，「回転体の空気力測定装置お よび空気力測定方法」，特許第 4982148 号, April 27, (2012)

7）高柳 庸一郎, 桑山 重光，「大気圧の変動による分銅 校正への影響」, 計測自動制御学会, 第 21 回 SICE セ ンシングフォーラム資料, pp. 369-374, (2004)

8) Tavares G., Shannon K. and Melvin T., "Golf Ball and Spin Decay Model Based on Radar Measurements", Science and Golf III, E.\& F. N. Spon., London, pp. 464-472, (1998)

9）溝田 武人, 下園 仁志, 鳴尾 丈司, 佐藤 文宣, M. M. Zdravkovich, 野口康雄, 「風洞気流中で高速回転する ゴルフボールの空力特性」, 日本風工学会誌, 第 79 号,pp. 163-164,(1999)

10）鳴尾 丈司, 道下 匡啓, 宮田 美文, 宇田 雅史, 溝田 武人, 田北 和幸, 「ゴルフボールのディンプルが空 力特性に及ぼす影響一新コンセプトのディンプルに よる空力特性および飛翔特性向上一」, 日本機械学会, [No 14-40], シンポジウム : スポーツ・アンド・ヒュ ーマン・ダイナミクス 2014, 講演論文集 B-29 (USB 資料), (2014)

11) Bearman, P. W. and Harvey, J. K., "Golf Ball Aerodynamics", Aeronautical Quarterly, 27, pp. 112-122, (1976) 